soon became librarian to that Society also. He continued his numismatic work for both societies. For the R.A.S. his most important work was the Manual of Musalmān Numismatics, already alluded to, but the following papers in our Journal may be noted :-

Notes on Musalman coins collected by Mr. G. P. Tate in Seistan : JRAS. 1904, p. 681.

Do. 1905 , p. 547.

Notes on coins collected in Seistan by Sir A. H. McMahon : JRAS. 1911, 3. 779.

Coinage of Husayn Baikara: JRAS. 1913, p. 432.

The following papers appeared in the Numismatic Chronicle:-

Coins of the Beni Rusūl, etc. : N.C. 1894, p. 88.

A coin of Taghlak Shāh : N.C. 1894, p. 185.

Coinages of Cutch and Käthiāwār : N.C. 1895, p. 59.

Coins of the Bahmani Dynasty: N.C. 1898, p. 259.

Some rare Oriental coins (Umayyad and 'Abbāsī) : N.C'. 1902, p. 267.

Coins of the King of Jinns: N.C. 1913, p. 123.

Of the papers those on the coins of Husayn Baikara, of the Bahmanis, and of Kachch are of great value.

Dr. Codrington's services to Numismatics were recognized by the bestowal on him of the Medal of the Royal Numismatic Society in 1911, an honour which he shared with such wellknown Oriental numismatists as Edward Thomas, Sir Alexander Cunningham, Stanley Lane-Poole, and Wladimir von Tiesenhausen.

M. Longworth Dames.

\title{
The Centenary of Sir Richard Francis Burton
}

On March 19 we celebrated the Centenary of one of Britain's noblest sons-Sir Richard Francis Burton.

His fame as an Orientalist and anthropologist was only surpassed by his ranking with the world's greatest explorers. 
Burton seems to have been drawn to Oriental languages from the earliest time, for when still at Oxford we find him teaching himself Arabic-individual coaching being then unknown. As soon as he had decided to join the Indian Army he began to sacrifice his boxing and fencing for the study of Hindustani.

He left England on June 18, 1842, to join the Native Bombay Infantry at Gujarat, and continued his Hindustani during the voyage: After proceeding to Baroda, Burton put in twelve hours' work a day, and as a result passed first in both Hindustani and Gujarati. An appointment to Sind as regimental interpreter followed, and very shortly another language--Maharàtta--was added to the other two languages in which Burton passed first. The list increased, and before he left India, Persian, Sindhi, Sanskrit, Punjabi, Pushtu, Arabic, Telugu, Turkish, and Armenian were added !

Apart from his books on India, Burton wrote two papers for the Journal of the Bombay branch of the Royal Asiatic Society, which were both published in Vol. III of the Journal for January, 1849. The first of these was "Notes and Remarks on Dr. Dorn's Chrestomathy of the Pushtu or Affghan Language" (pp. 58-69), and the second was "A Grammar of the Jātāki or Belochki Dialect"' (pp. 84-125).

A long furlough in England prompted Burton to carry out a project he had already formed in Sind to study the "inner life of the Moslem", and so, after obtaining a year's special leave, he started on his famous journey to Mecca and Medina in 1853. It would be superfluous to give details of the great journey, for it will remain for all time as one of the most hazardous and intensely interesting journeys ever recorded. His Personal Narrative of a Pilgrimage to El-Medinah and Meccah, 1855-6, is now a classic, and ranks among the world's greatest travel books.

Immediately after the pilgrimage began Burton's great career as an African explorer, and had the Government of that day looked favourably upon him there is no knowing to what heights he would have risen. 
In 1861 Burton married Isabel Arundell, and entered the service of the Foreign Office the same year. He held four Consulates-Fernando Po (1861-5), Santos, Brazil (1865-9), Damascus (1869-71), and Trieste.(1872-90). Although exiled at Trieste, a place ill-suited to his health, Burton was able to obtain leave frequently, and we find him paying a return visit to India (1875-6), where he continued the study of his beloved Camöens, exploring Midian·(1877-9), from an archæological and mineralogical point of view, and seeking gold on the Gold Coast (1881-2). All this time Oriental and anthropological details were slowly being collected in his numerous note-books, and most of this mass of information found its way into his great translation of Alf Laylah wa Laylah-the Thousand Nights and a Night.

There is no room here to discuss this work in detail, to compare it with the translations of Lane, Payne, and Mardrus, and to speak of the various MSS. used. Suffice to say that Burton's translation is the one always chosen for Oriental students who want to translate word for word and see exactly the original sense of any particular passage. In order to preserve the spirit of the original as much as possible, Burton retained the Saj'a or cooing of a dove-the passages in cadenced prose which appear as little eddies of song set like gems in the story.

Writers have often commented adversely on Burton's constant use of archaic or foreign words, but he was merely carrying out the difficult task he had set himself-to translate noun for noun and verb for verb. The composite nature of the MSS. produced local and uncommon words, to meet which no modern English equivalent existed, thus by using fourteenth and fifteenth century words he not only translated literally, but preserved the spirit, naïveté, and atmosphere of the mediaeval East. Although not a classical Oriental scholar, his practical knowledge of the East will always stand alone and unsurpassed.

Of his personal character there still remain some who can 
speak with real knowledge ; but those few who were honoured with his intimacy, those few who probed beneath the rugged surface-they know what a jewel lay hid for those who cared to seek, and to-day hold the memory of his friendship as the most sacred possession of their lives.

It is not inappropriate to sum up this slight tribute to his memory with a few lines from his well-known "Kasidah " :-

True to thy Nature, to Thyself, Fame and Disfame nor hope nor fear ;

Enough to thee the small still voice aye thund'ring in thine inner ear.

$* \quad * \quad * \quad * \quad * \quad * \quad *$

This "I" may find a future Life, a nobler copy of our own,

Where every riddle shall be ree'd, where every knowledge shall be known;

N. M. Penzer.

\section{Maulvi Shaikh Laiqahmad Ansari, M.A.S.B., M.R.A.S.}

The late Maulvi Shaikh Laiqahmad Ansari, an Oriental scholar of Delhi, came of the family of Shaikh Ansarian of Kairana (U.P.).

Mr. Ansari was for inany years on the Staff of the Morning Post of Delhi. He was the author of the Urdu Self Instructor and Idiomatic Urdu for Public Speeches, and was a warded a grant from the Government of the Punjab for the first-named publication, which has been pronounced as most useful by prominent educational authorities. The second book was dedicated by permission to the late Lord Minto, when Viceroy of India, and Mr. Ansari received autograph letters from Lord Ampthill and Sir James Latouche eulogizing the book.

His brilliant scholarship won for him a great reputation in the country, and he was sent on a deputation to Calcutta by Her Highness the Begum of Bhopal in connexion with research work.

Nazeer Ahmad Ansari. 